Journal of Social Sciences (COES\&RJ-JSS)

ISSN (E): 2305-9249 ISSN (P): 2305-9494

Publisher: Centre of Excellence for Scientific \& Research Journalism, COES\&RJ LLC

Online Publication Date: $1^{\text {st }}$ October 2019

Online Issue: Volume 8, Number 4, October 2019

https://doi.org/10.25255/jss.2019.8.4.788.804

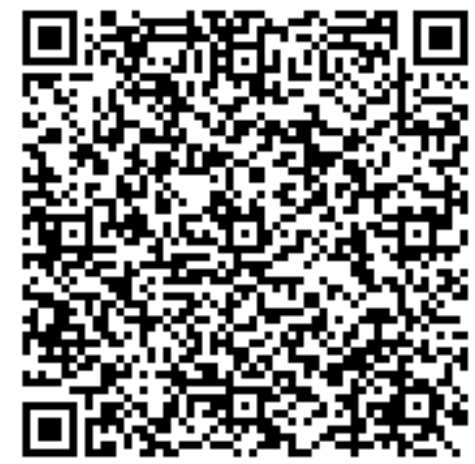

\title{
The Effects of Canonity and the Authorial Weight in Translating Dickens' Oliver Twist into Arabic Language Ibrahem Bani Abdo
}

Assistant Professor, English Department Aqaba, University of Jordan, Jordan http://orcid.org/0000-0003-1366-4167 ibrahim_re@yahoo.com

Batool Abu-Faraj

MA in Translation, Faculty of Foreign Languages, University of Jordan, Jordan batool.majed@gmail.com

\begin{abstract}
This research investigates whether 'canonity and authorial weight' affect the translation product of Charles dickens' Oliver Twist, and whether the source text (English) aesthetic features are maintained in the target text (Arabic). It aims to link aesthetic features with the figurative elements that are used in the translation which may express the role the authorial weight plays in the translation process. The importance of preserving the author's intended meaning of the source text (SL) in the target language is crucial. Consequently, this research uses a comparative qualitative research analysis that compares two randomly Arabic translations (TT1 and TT2) with the source text (ST) according to canonity and authorial weight features. The features of figurative language are located in the source text (ST) then compared to their counterparts in the target text (TTs). The random sample discussed thoroughly of whether it is equivalents to ST. This study is based on Nida's (1975 \& 1964) dynamic or formal equivalence backgrounds. It concludes that figurative elements in translation play a major role in the fluency of the translator taking into the translators' authorial weight
\end{abstract}

This work is licensed under a Creative Commons Attribution 4.0 International License. 
in the target language. It also concludes that the translation is affected by the canonity and aesthetic features used.

\section{Keywords:}

Authorial weight, aesthetic features, canonity, Dickens' Oliver Twist, figurative elements, translation

\section{Citation:}

Bani Abdo, Ibrahem; Abu-Faraj, Batool (2019) ; The Effects of Canonity and the Authorial Weight in Translating Dickens' Oliver Twist into Arabic Language; Journal of Social Sciences (COES\&RJ-JSS), Vol.8, No.4, pp:788-804;

https://doi.org/10.25255/jss.2019.8.4.788.804.

\section{Introduction}

This research investigates if the target equivalents' (TT1 and TT2) can/ cannot be achieved without professional translators or authors who have the same authorial weight as the original author. Figuring out the aesthetic features and the figurative elements in the source text (ST) and compare it with its counterparts in TTs that is implied by authoritative translators. It illustrates the canonity of Charles Dickens' Oliver Twist, which is considered as a canon work, compared to its Arabic equivalent translations (TT1, and TT2) by Ba'albki (2007) and Shanaway (2013).

Translation has been regarded as equivalent representation of linguistic structures, and translation studies have long been concerned with different levels of text equivalence (Jiang, 2008; Bajnaid et al., 2019). Ural and Akdağ (2017) indicate that translating a literary work can be analyzed from various points of view. Multidimensional implications of both source and target cultures and languages are involved. Figurative language is also must be clearly indicated in the translation process and it is considered much more than replacing words between languages. In addition, these qualities as its defining characters are not given as readymade or finally formed realities, but as possibilities or inherent images for realization. They emerge as gestalt in the activity of aesthetic faculties, waiting to be actualized in the interaction with the translator (Jiang, 2008).

\section{The statement of the problem}

The importance of the authorial weight and canonity is rarely taken into accounts in translation. Many Arabic translators would translate any type of work with no sense of canonity for the original author and what might do that mean. Therefore, this study focuses on the authorial weight and canonity and how this may could affect the translation. As a result, this study discusses Charles Dickens's canonity and authorial weight in his masterpiece Oliver Twist and two Arabic translators. Charles Dickens is very known writer. He was indeed very much a public figure, actively and centrally involved in his world, and a man of 
confident presence (Gasson, 1998). Therefore, knowing the canonity and the authorial weight of the author in any canon literary work is crucial in a text to be translated. This issue may lead to misunderstanding the ST compared to its translations (Arabic language). Though, having a canon translator may represent the same quality of the ST.

\section{Research questions}

As many translation theories mention the affects of canonity on the published literary work, canonity may affect also the translated work as well. Therefore; this paper investigates whether (i) 'canonity and authorial weight' affect the translation product of Charles dickens' Oliver Twist, and (ii) whether the ST aesthetic features are maintained in the TTs?

\section{Significance of the study}

Literary text is universally recognized as work of art, which contains aesthetic essence within and beyond the linguistic structure. It is constituted by the possession of aesthetic qualities as a necessary though not perhaps a sufficient condition. Consequently, the translator must have a high degree of ability to represent certain combinations of the ST. Aesthetic features are such example of these combinations (Jiang, 2008, p. 864). This study includes the study of these features with a canon work and a canon author. This study discusses whether canonity and the authorial weight of Charles Dickens in the history of English literature and in the 19th century are represented in the target texts (TTs). It also shows the quality of translation where it may affect the original literary work, e.g. it may make the work lose or maintain its value.

\section{Effects of Canonity and the Authorial Weight in Translation}

Munday (2001) defines translation as it can be referred to the general subject field, the product (the text that has been translated) or the process (the act of producing the translation, otherwise known as translating). He adds that the process of translation between two different written languages involves the translator changing an original written text (the ST) in the original verbal language (the $S L$ ) into a written text (the $T$ ) in a different verbal language (the TL). Nida (1964) defines translation as "Translating consists in reproducing in the receptor language the closest natural equivalent of the source language message, first in terms of meaning and secondly in terms of style". (p.12)

Wheeler (2015) states that the term canon has three generally accepted senses: (i) an approved or traditional collection of works. Originally, the term "canon" applied to the list of books to be included as authentic biblical doctrine in the Hebrew and Christian Bible, as opposed to apocryphal works (works of dubious, mysterious or uncertain origin); (ii) today, literature students typically use the 
word canon to refer to those works in anthologies that have come to be considered standard or traditionally included in the classroom and published textbooks. In this sense, "the canon" denotes the entire body of literature traditionally thought to be suitable for admiration and study; and (iii) in addition, the word "canon" refers to the writings of an author that scholars generally accepted as genuine products of said author, such as the Chaucer canon or the Shakespeare canon. Chaucer's canon includes The Canterbury Tales (Wheeler, 2015).

Along with their texts, authors have significant weight or authority (Haan, n.d.). Winning the Nobel Prize is an indication of an author's authorial weight in literature (Trodd, 2007), researcher explains why we consider, the famous writer Charles Dickens and his "Oliver Twist" with its Arabic equivalent by the translator Ba'albaki, them as famous and huge things. Bani Abdo (2017) writes: "we can initially characterize a literary canon as a group of literary works that are considered 'authoritative', i.e. having central status in the literature of a particular time period and/or place". He adds that the notion of authority is hard to determine and leaves us with the key question of who has the power to determine what works are worth reading and teaching, and to be considered as canonical.

Williams and Chesterman (2014) defines professionalism as a translator has the competences required for translation or interpreting services and constantly tries to improve them, so it means that she/he is striving for excellence. Alwazna (2014) writes that translation as an important profession and as an enjoyable activity has been variably viewed by different translation scholars and translator. Nord (1997) sees the first step in the translation process is the interpretation of the brief, drawing on whatever information there is or can be obtained about the profile of the target text the client needs. She adds that translation is offered by translators of capability and it may cause problematic issues especially in the medical or the legal fields.

Pym (2012) believes that there are limits to the translator's professional responsibility. According to Pym (2012) there are many responsibilities that the translator should take into account such as: responsibility to the content of the text, responsibility to the client, and responsibility to the profession. According to Baker and Maier (2014), professional translators have started to show particular interest in translation ethics, which emanates from their belief that they have become influential figures in the movements of human rights that mark today's world. 


\section{Figurative language and aesthetic experience in a translated text}

This paper tries to figure out if the authorial weight of translators appears in the translated text into its equivalents $\Pi$ (Arabic) by showing and improving its aesthetic features and figurative elements. Figurative language is a language that is difficult to understand by those who are less aware of the meaning that embedded in the words or phrases (Abdul Wahid, 2017). In addition, figurative language is one of the features that give literature its distinctiveness in the form of the "suggestion or indirection, and imagination or invention" that characterize its method of expression (Egudu, 1979).

Figurative elements mostly carry meaning beyond what is written or told (Pierce et al., 1932). Abdul Wahid (2017) says that "translating figurative language not only requires the knowledge of the language and cultures of both source and target language" (p. 1). He adds that translating figurative language needs a deep understanding and should be interpreted to get the actual meaning. Abrams (1988) states that figurative language involves a deviation from what speakers of a language apprehend as the ordinary or standard significance or sequence of words, in order to achieve some special meaning or effect. Furthermore, figurative employs to indicate the speaker's deep perception of or emotive identification with the idea being expressed. It is also freely adopted for general oratorical effect (Teilanyo, 2007).

Akdağ and Ural (2017) illustrates that the translated literary works can be analyzed from various points of view. They involve multidimensional implications for both source and target cultures and languages. Figurative elements are one of the detailed framing of the language used in the novel which in turn helps in linking the figurative language that the qualified translator uses in his/her translation and the figurative language that the unqualified translators use in their language. Figurative language is important in terms of the cultural aspects too. However, translating figurative language is more than just handling terminology. In the $\mathrm{TL}$, It is presented in an accurate complete possible form and that the information can be used correctly and effectively (Abdulla, 1994).

There are four challenges in translating figurative language that are highlighted by Baker (1992) as follows. A figurative language has no equivalent in the target language, a figure of speech might have the same equivalent in the target language, but may vary with the context, a figure of speech in the source language may be translated literally and idiomatic in the target language, and the use of figurative language in writing discourse, context and frequency of usage may differ with the source language and the target language. She also adds two translation procedures for figurative language that used in translation. The first procedure is using a figure of speech that is similar in meaning and form, and the 
second is the use of figurative language is similar in meaning, but differs in form and the last is translated by the paraphrase.

Figurative language refers to a non-literal meaning of a word or a phrase (Nida, 1975). This may happen in any literary text especially while having the sense of aesthetic features in the figurative language. This in turn shows the importance of using aesthetic features in literary translation because aesthetic features are stylistics features that are used by the original author to fulfill different messages as Zhang (2008) states. He adds that the translator must take these features into account between a source text and a target text.

Jiang (2008) explains that the translator must have a high degree of ability to represent, in the mind's eye, certain combinations of the ST, like a painter who has an uncommon visual imagery, the musician auditory imagery; the translator must have verbal imagery. Art is what it has become its concept refers to what it does not contain (Adorno et al., 2002). They add that the tension between what motivates art and art's past circumscribes the so-called questions of aesthetic constitution. The gesture of experimentation, the name for artistic comportments that is obligatorily new has endured but now, keeping with the transition of aesthetic interest from the communicating subject to coherence of the object, it means something qualitatively different.

Zhang (2008) explains that different translators with different operations of psychological faculties might produce different comprehension of a literary text, hence different translated versions, and this point is described by the personalized aspect in the following way: In the same way two people gazing at the night sky may both be looking at the same collection of stars, but one will see the image of a plough and the other will make out a dipper. The stars in a literary text are fixed; the lines that join them are variable (Viehoff, 1986). In the aesthetic progression the translator is required to perceive the images.

The aesthetic experience is the imaginative faculty of the translator. Jiang (2008) adds that translation usually projects a certain image in the service of a certain ideology, and this fact is most apparent in the altered images in the translations. Some translators have tried to make the reproduced images fit their ideology by using all kinds of manipulative techniques, while other translators try to merge the poetics of the original with a poetics acceptable in their own ideology.

Zhang (2008) writes that the images in the literary texts simply refer to mental pictures, influenced by the author's moods or feelings, which need to be evoked and reproduced by the translator's imagination, and the translator is unconsciously concerned about expressing visual images. Although, Zhang insists upon getting the exact arrangement of words to express attitudes, ideas, and 
even moods, as well as a piece of literary works is usually composed of a series of images. The transition from the images into target-language exponents would produce more effective and equivalent translations than item for item replacement, and it is therefore indispensable for a good translator to comprehend the text in various manifested aspects through aesthetic actualization of the images; during this kind of translating process imagination is actually involved in the image actualization (Zhang, 2008).

\section{Methodology}

Two passages were randomly chosen from Charles Dickens's "Oliver Twist" and their Arabic equivalents ( $B a^{\prime} a l b a k i, 2017$; and Shanaway, 2013). This research is a comparative qualitative research analysis that compares the two passages according to the canonity and authorial weight features. As Dickens is considered a canon author; whereas, Ba'albaki is very well-known but Shanaway is not canon or has no authorial weight at the time.

Each translation will be then compared through the use of the aesthetic features and the figurative elements and to find out whether TT1 and TT2 maintain these aesthetic features in TTs. These features of figurative language will be first located in the ST then would be compared to their counterparts in TTs. These figurative elements related to canonity and authorial weight which is considered to be creative aspect of Dickens and would be analysed in the TTs. Classifying the canon author in compared to the two translators and how well are to have authorial weight or not. The data (random sample) will be discussed thoroughly in terms of whether it equivalents to the aesthetic features of the ST. This sample will also be classified into the different strategy of Nida's (1964) dynamic or formal equivalence. The images in the ST are also represented in TTs (Zhang 2008).

\section{Data Analysis}

Table 1. The random texts passages taken from the source text (ST)

\begin{tabular}{|l|l|}
\hline No. & ST \\
\hline 1 & $\begin{array}{l}\text { Among other public buildings in a certain town, which for many reasons it } \\
\text { will be prudent to refrain from mentioning, and to which I will assign no } \\
\text { fictitious name, there is one anciently common to most towns, great or } \\
\text { small: to wit, a workhouse; and in this workhouse was born; on a day and } \\
\text { date which I need not trouble myself to repeat, inasmuch as it can be of no } \\
\text { possible consequence to the reader, in this stage of the business at all } \\
\text { events; the item of mortality whose name is prefixed to the head of this } \\
\text { chapter. }\end{array}$ \\
\hline 2 & $\begin{array}{l}\text { For a long time after it was ushered into this world of sorrow and trouble, } \\
\text { by the parish surgeon, it remained a matter of considerable doubt whether }\end{array}$ \\
\hline
\end{tabular}




\begin{tabular}{|l|l|}
\hline & $\begin{array}{l}\text { the child would survive to bear any name at all; in which case it is } \\
\text { somewhat more than probable that these memoirs would never have } \\
\text { appeared; or, if they had, that being comprised within a couple of pages, } \\
\text { they would have possessed the inestimable merit of being the most concise } \\
\text { and faithful specimen of biography, extant in the literature of any age or } \\
\text { country. }\end{array}$ \\
\hline 3 & $\begin{array}{l}\text { The surgeon had been sitting with his face turned towards the fire: giving } \\
\text { the palms of his hands a warm and a rub alternately. As the young woman } \\
\text { spoke, he rose, and advancing to the bed's head, said, with more kindness } \\
\text { than might have been expected of him: 'Oh, you must not talk about dying } \\
\text { yet.' 'Lor bless her dear heart, no!' interposed the nurse, hastily depositing } \\
\text { in her pocket a green glass bottle, the contents of which she had been } \\
\text { tasting in a corner with evident satisfaction. 'Lor bless her dear heart, when } \\
\text { she has lived as long as I have, sir, and had thirteen children of her own, } \\
\text { and all on 'em dead except two, and them in the wurkus with me, she'll } \\
\text { know better than to take on in that way, bless her dear heart! Think what it } \\
\text { is to be a mother, there's a dear young lamb do.' Apparently this } \\
\text { consolatory perspective of a mother's prospects failed in producing its due } \\
\text { effect. The patient shook her head, and stretched out her hand towards the } \\
\text { child. The surgeon deposited it in her arms. She imprinted her cold white } \\
\text { lips passionately on its forehead; passed her hands over her face; gazed } \\
\text { wildly round; shuddered; fell back- and died. The blood had stopped } \\
\text { forever. They talked of hope and comfort. }\end{array}$ \\
\hline
\end{tabular}

Table 2. The target text (TT1) passages' equivalents

\begin{tabular}{|c|c|}
\hline No. & TT1 (Ba'albaki) \\
\hline 1 & 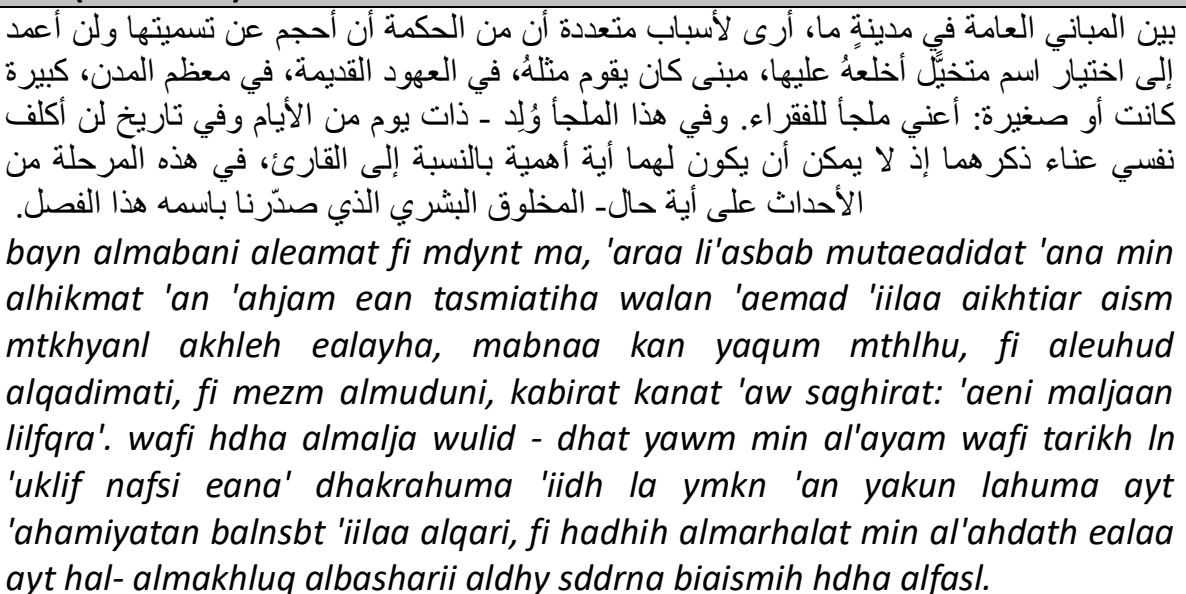 \\
\hline 2 & 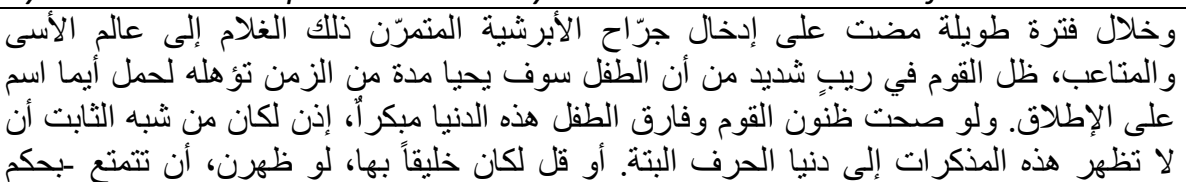 \\
\hline
\end{tabular}




\begin{tabular}{|c|c|}
\hline & 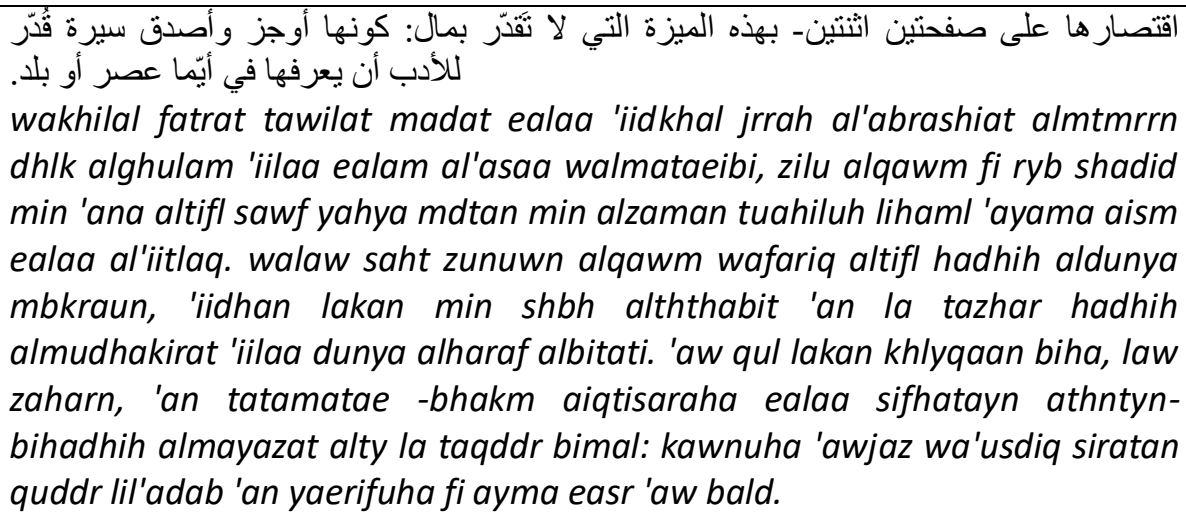 \\
\hline 3 & 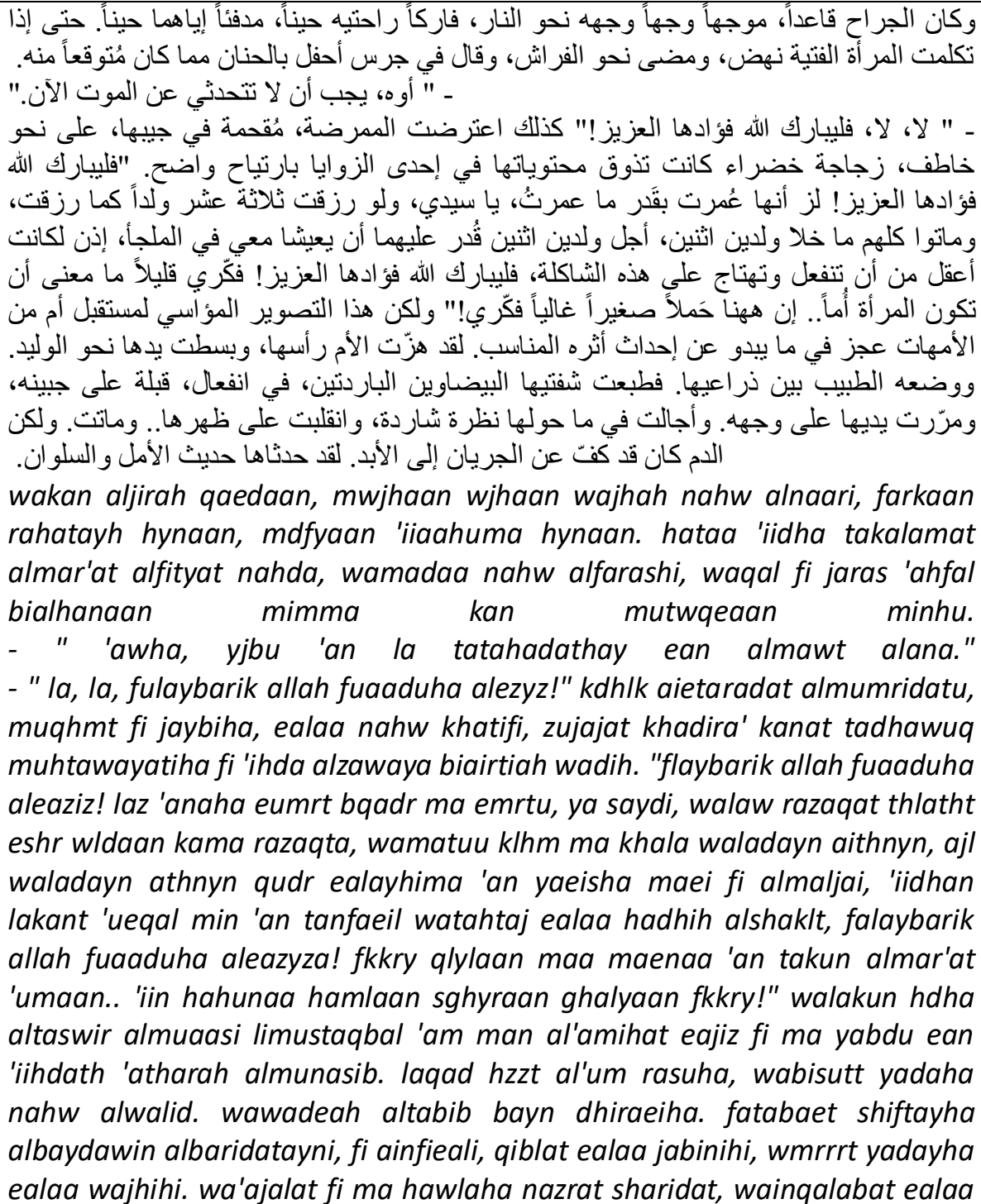 \\
\hline
\end{tabular}


zahrha.. wamatat. walikuna aldam kan qad kf ean aljuryan 'iilaa al'abd. laqad hudthaha hadith al'amal walsulwan.

Table 3. The target text (TT2) passages' equivalents

\begin{tabular}{|c|c|}
\hline No. & $2(\mathrm{Sn}$ \\
\hline 1 & 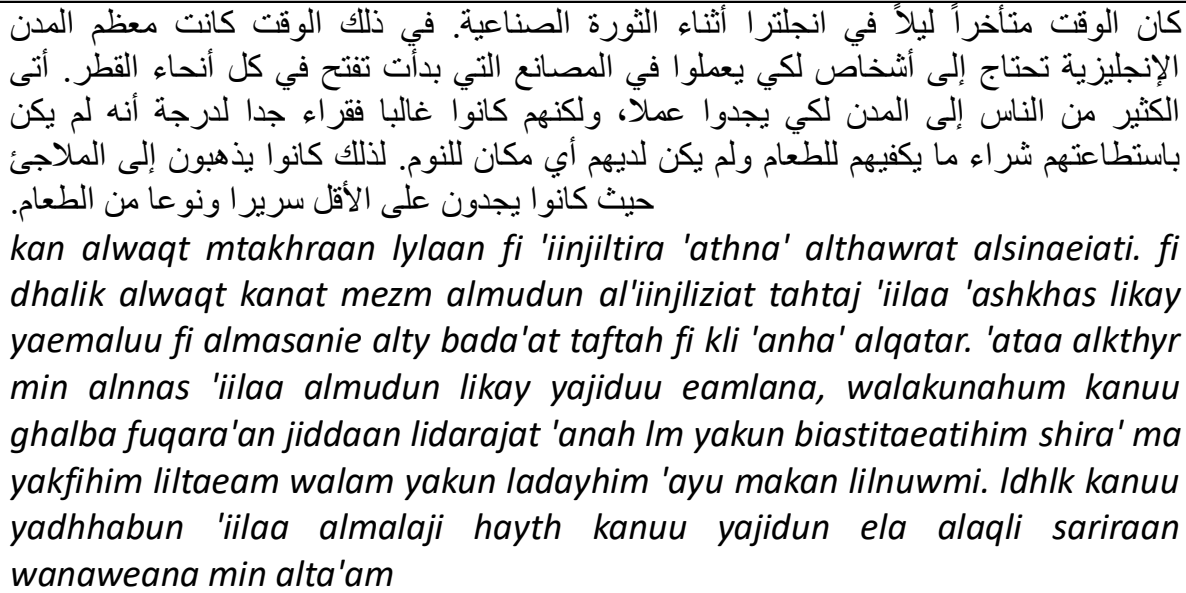 \\
\hline 2 & 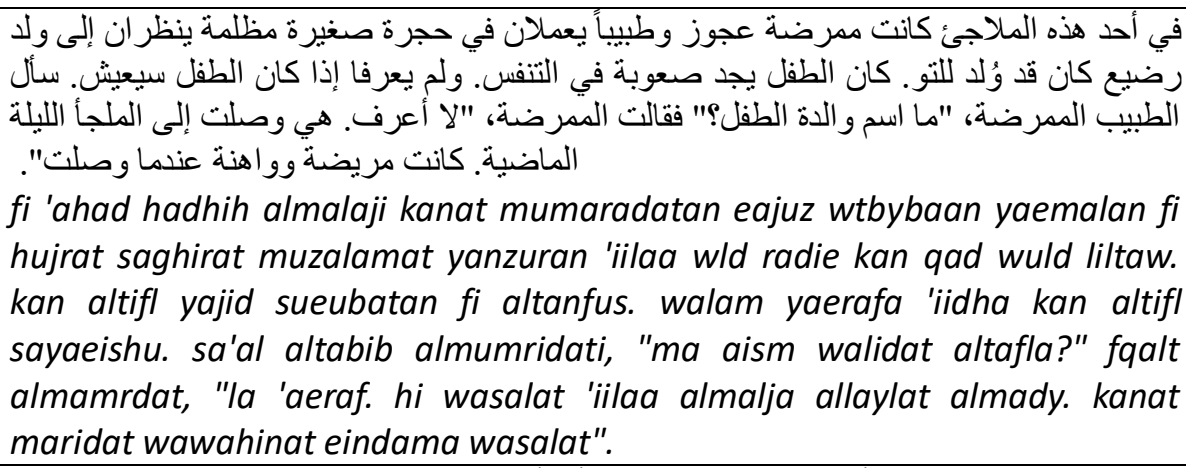 \\
\hline 3 & 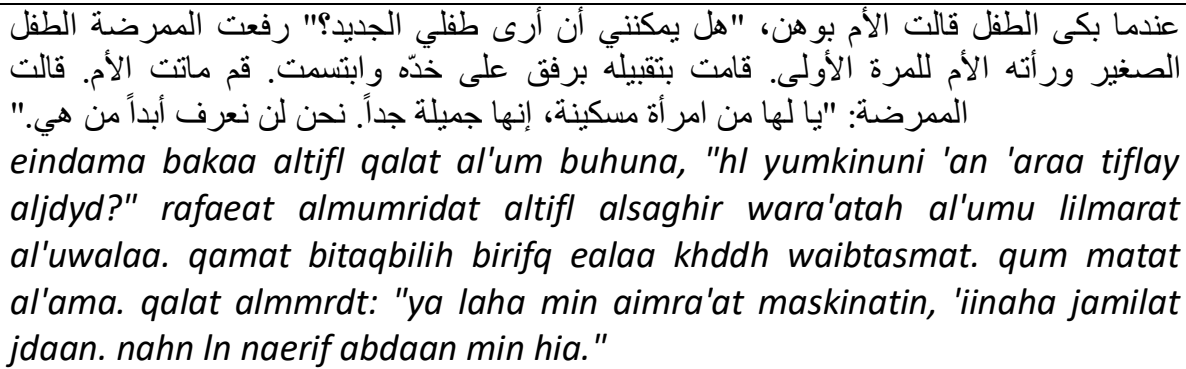 \\
\hline
\end{tabular}

These chosen texts (ST, TT1, and TT2) show that Dickens starts his novel by portraying the place of the story. Dickens (ST) used these words (public buildings, town, workhouse, parish surgeon, couple of pages, and child) to indicate the location. TTs use words in the TL (Arabic) that made a noticed change in understanding the original text as in the following table. 
The Effects of Canonity and the Authorial Weight...

Table 4. Words used in the target language (TL)

\begin{tabular}{|c|c|c|c|}
\hline No. & Words used in TL & Transliteration & Meaning \\
\hline 1 & بين المباني العامة & bayn almabani aleamat & public buildings \\
\hline 2 & المدن الإنجليزية & almudun al'iinjliziat & British towns \\
\hline 3 & الطفل & altifl & child \\
\hline 4 & الطبيب & altabib & surgeon \\
\hline 5 & أنحاء القُطر & kli 'anha' alqatar & in the country parts \\
\hline 6 & الثورة الصناعية & althawrat alsinaeiati & industrial revolution \\
\hline 7 & جرّاح الأبرشيّة & jrrah al'abrashiat & Parish surgeon \\
\hline 8 & 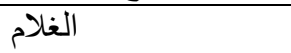 & alghulam & child \\
\hline 9 & صفحتين اثتنين & sifhatayn athntyn & couple of pages \\
\hline
\end{tabular}

Table 5 shows the different words choice of translating the ST.

Table 5. The target language (TL) different words choice

\begin{tabular}{|c|c|c|c|c|c|}
\hline No. & SL & TT1 & Transliteration & TT2 & Transliteration \\
\hline 1 & $\begin{array}{l}\text { Public } \\
\text { buildings }\end{array}$ & |المباني العامة & \begin{tabular}{|l} 
almabanī \\
al'ama
\end{tabular} & ---------- & --------- \\
\hline 2 & Child & |الطفل & atifel & ولا رضيع & wald rade' \\
\hline 3 & $\begin{array}{l}\text { The parish } \\
\text { surgeon }\end{array}$ & جرّاح الأبرشيّة & $\begin{array}{l}\text { jrrah } \\
\text { al'abrashiat }\end{array}$ & الطبيب & attabib \\
\hline 4 & $\begin{array}{l}\text { Couple of } \\
\text { pages }\end{array}$ & صفحتين اثتتين & $\begin{array}{l}\text { safhatin } \\
\text { ethnatain }\end{array}$ & - & \\
\hline 5 & --------- & ---------- & ---------- & المُدن الصناعيّة & $\begin{array}{l}\text { almudun } \\
\text { assenaaya }\end{array}$ \\
\hline 6 & |--------- & --------- & |--------- & كان الوقتُ متأخر اً & $\begin{array}{l}\text { kana alwaqtu } \\
\text { mata'kheran }\end{array}$ \\
\hline
\end{tabular}

The equivalents of the ST for this sample are varying. The way each translator translates the text and the procedures they used is different. Both translations make sense for reader. Some words make a special taste for the whole text. Ba'albaki uses literal translation with taking into account the source text. Ba'albaki uses Nida's procedure in his translation equivalents (Nida, 1964) states that there are two basic orientations or types of equivalence in translation: (1) formal equivalence and (2) dynamic equivalence. He adds that the formal equivalence focuses attention on the message itself, in both form and content. Also, he focuses on the content by preparing it in very well form too so reader can taste the text with its scenes and images. Table 5 indicates the following results.

- It shows that some words have more formal equivalents in $\mathrm{Ba}^{\prime}$ albaki's translation (TT1) as in the parish surgeon, which has been translated into جرّ اح الأبرشيّة 'jrah 
al'abrashiat. As well as the term child, which has been translated into altif الطفل . These two terms (the parish surgeon and child) don't have the same accuracy equivalents as in Shanaway's translation (TT2). The term altabib الطبيب doesn't exactly represent the term the parish surgeon. As well as the term ولد رضيع wald radi'a doesn't exactly represent the word child.

- Ba'albaki's tends to match TT1 with the ST; whereas, Shanaway (TT2) adopts a strategy related to the target language (Arabic) culture. This result indicates that there is ordinarily no full equivalence between code-units (Baker, 1992). Jakobson (1976) believes that there is "no exact synonyms between languages, Shanaway adds extra words that are not mentioned in the original text such as althawrat alsinaeiati الثورة الصناعية and كان الوقت متأخراً ليلاً في إنجلتر kan alwaqt mtakhraan lylaan fi 'iinjiltira.

- Adorno (1997) also mentions that the aesthetic experience should reflect the aesthetic interest of the writer to communicate in the subject and coherency. This means something qualitatively different. Shanaway's translation (TT2) uses the term الثورة الصناعية althawrat alsinaeiati which is not used in the ST to express the industrial revolution happened in England at the time.

- Shanaway (TT2) uses a dynamic equivalence by using extra and informative words that suits the Arabic readers (Nida, 1964). This shows how figurative language has been represented in Shanaway's translation (TT2). As mentioned before, some translators have tried to reproduce images that can fit their ideology by using manipulative techniques.

- Ba'albaki's translation (TT1) matches the same ideas of the ST; whereas, TT2 does not exactly match the ST. The following example is represented in table (6) (Among other public buildings in a certain town, which for many reasons it will

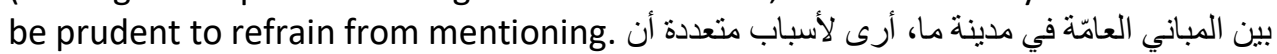
bayn almabani aleamat fi mdynt ma, 'araa li'asbab mutaeadidat 'ana min alhikmat 'an 'ahjam ean tasmiatiha walan 'aemad 'iilaa aikhtiar aism mtkhyanl akhleh ealayha).

Table 6. Phrase example extracted

\begin{tabular}{|c|c|c|c|}
\hline No. & SL & TL & Transliteration \\
\hline 1 & Among & بين بين & bayna \\
\hline 2 & Buildings & المباني & almabani \\
\hline 3 & Public & العامة & al'ama \\
\hline 4 & In a certain town & في مدينة ما & fi madina ma \\
\hline 5 & For many reasons & لأسباب متعددة & la'sbaab mat'adida \\
\hline 6 & From prudent & من الحكمة & man alhekma \\
\hline 7 & To refrain & ان يحجم / ان يمنع & an yahjum / an yamna \\
\hline 8 & Mentioning & تسميتها & tasmiatuha \\
\hline
\end{tabular}

- Zhang (2008) states that the translator is unconsciously concerned about expressing visual images, although he insists upon getting the exact arrangement 799 
of words to express attitudes, ideas, and even moods. Ba'albaki's translation (TT1) uses the same exact arrangement of the ST as shown in table 6 .

- The following translations of TT1 حتى المرأة الفتية نهضت، و قال في جرسٍ احفل بالحنان

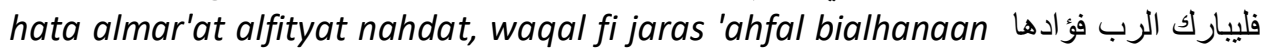
altaswir almuaasi limustaqbal 'am بسطت يدها نحو الوليد، wabisutt yadaha nahw alwalid اجالت fatabaet shiftayha albaydawin albaridatayni فطبعت شفتيها البيضاوين الباردنين، حدّثاها حديث الامل wa'ajalat fi ma hawlaha nazrat sharidat, في حولها نظرة شاردة، hudthaha hadith al'amal walsulwan. The aesthetic features used in TT1 portray the full image of the ST. This figurative language involves the well known translator and author (Ba'albaki) who has authorial weight. This translation indicates a profession of the translator where he uses the formal and dynamic equivalence in (TT1). This involves that the translator must have a high degree of ability to re-present, in the mind's eye, certain combinations of the ST, like a painter who has an uncommon visual imagery, the musician auditory imagery; the translator must have verbal imagery. Zhang (2008) states that the images in the literary texts simply refer to mental pictures, influenced by the author's moods or feelings, which need to be evoked and reproduced by the translator's imagination, and the translator is unconsciously concerned about expressing visual images. This figurative language is clearly shown in Ba'albaki's translation (TT1) such as (صحت الظنون، دنيا الحرف البته، بحكم اقتصار ها على صفحتين ريبٍ شديد ) as in the following paragraph. These following paragraphs show that $B a^{\prime}$ 'albki has lived this experience by his uncommon visual imagery in his mind, and he shows us that he is in the place at the same time (Jiang, 2008).

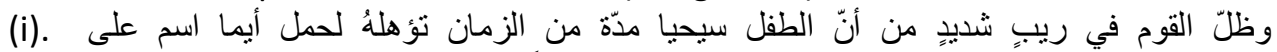

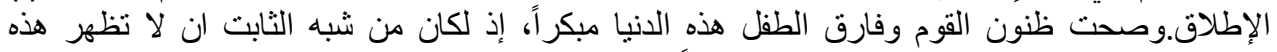

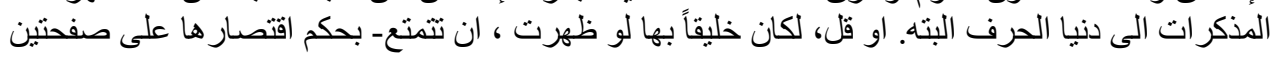
(zilu alqawm fi ryb shadid min 'ana altifl sawf yahya mdtan min alzaman tuahiluh lihaml 'ayama aism ealaa al'iitlaq. walaw saht zunuwn alqawm wafariq altifl hadhih aldunya mbkraun, 'iidhan lakan min shbh alththabit 'an la tazhar hadhih almudhakirat 'iilaa dunya alharaf albitati. 'aw qul lakan khlyqaan biha, law zaharn, 'an tatamatae -bhakm aiqtisaraha ealaa sifhatayn athntyn-bihadhih almayazat alty la taqddr bimal).

(ii). حتى المرأة الفتية نهض، جرسِ احفل بالحنان مما كان متوقعاً منه (hata almar'at alfityat nahda, wamadaa nahw alfarashi, waqal fi jaras 'ahfal bialhanaan mimma kan mutwqeaan minhu).

- Ba'albaki's translation (TT1) represents a certain image in the service of a certain ideology; whereas, other translators try to merge the poetics of the original with a poetics acceptable in their own ideology. Adding, the social and cultural diversities may make the pursuit of simpatico difficult if not impossible for the intra-lingual translator. 
- There is immense match coherence between Dickens's Oliver Twist's (ST) ideology and its equivalent $\Pi T 1$ ( $\left.B a^{\prime} a l b a k i\right)$. TT2 translation is a direct language without take into account the literal translation of the ST. TT2 uses omission and replaces other terms that involves the readers' language as in the following examples; يعملان في حجرة صغيرة مظلمة yaemalan fi hujrat saghirat muzalamat; wld

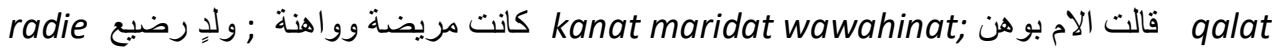

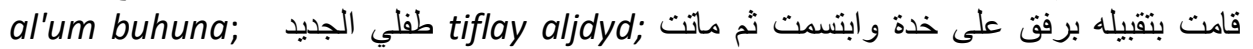

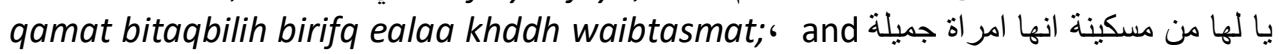
ya laha min aimra'at maskinatin, 'iinaha jamilat jdaan.

- Shanaway (TT2) uses very brief, short, and clear words. He replaces the procedure of literal translation with the use of short and deep and brief figurative language. This shows that the use of figurative language in translation involves a deviation from what speakers of a language apprehend as the ordinary or standard significance or sequence of words, in order to achieve some special meaning or effect as (Abrams 1988).

- Figurative language employs the speaker's deep perception of or emotive identification with the idea being expressed. Shanaway's translation (TT2) includes that translating figurative language not only requires the knowledge of the language and cultures of both source and target language, but also choosing the appropriate word and translation strategies as shown in table 7.

- TT2 characterizes the literary text by using figurative and aesthetic ways. TT2 methods that are not the same as in the ST as shown in Table 7.

Table 7. The target text (TT2) example as a figurative language

\begin{tabular}{|c|c|c|}
\hline ST & TT2 by Shanaway & Transliteration \\
\hline $\begin{array}{l}\text { As the young woman } \\
\text { spoke }\end{array}$ & قالت الام بوهن & qalat al'um bewahan \\
\hline ------ & كانت مريضة وو اهنة & $\begin{array}{l}\text { kanat maridat } \\
\text { wawahinat }\end{array}$ \\
\hline Child & يا لها من مسكينة انها امر اة جميلةً رضيع & $\begin{array}{l}\text { wld radie } \\
\text { ya laha min aimra'at } \\
\text { maskinatin, 'iinaha } \\
\text { jamilat jdaan }\end{array}$ \\
\hline
\end{tabular}

- Shanaway (TT2) makes many changes to the ST. He deletes too details and replaces these details by using figurative and meaningful words. He adapted the target language features. Shanaway uses dynamic equivalents in TT2. He uses figurative simple words to be more expressive than translating literal one or word by word.

\section{Conclusion}

The study concludes that the translation of Ba'albaki (TT1) is very meaningful and helpful. He uses clarified procedures while translating, and he takes into his 
account both the formal and dynamic translation for the source text (Nida 1964). Because of his authorial weigh, he applies the aesthetic features, the figurative language and the tasteful senses to his translation. Ba'albaki (TT1) is very smart in his translation. He takes care of Nida's dynamic and formal equivalent in translation because this text is a literary text. Reader wants to enjoy while reading it, and they want to taste every word and scene in the novel (Wheeler, 2015). On the other hand, Shanaway (TT2) translation tends to be very brief. He doesn't take into his account the sensitivity of the literary text as a canon and big work. The reader of any literary work is thirst to read more and in details. Reader wants to taste the literature as it is with no deletion and no omission.

Dickens's work already has its authorial weight, Dickens too. So, the translator of any canon work should be more careful while translating the literary work (Wheeler, 2015). There is no exact translation, but there is more accurate translation than another. The authoritative translator, like Ba'albaki, knows how to preserve author's intended meaning of the ST (Zhang, 2008).

From researchers' point of view, there is a relationship between the authorial weight of a work and the translator and his/her proficiency in translating or writing. Ba'albaki (TT1) has his authorial weight to some extent, and he translates the text in a very reprehensive form similar to the ST. Reader of his translation still can taste the sense of literature and Dickens's touch in his literary work; whereas, Shanaway translation (TT2) has lost the sense of literature, it seems that his translation is for educational issues not for enjoying Dickens's Oliver Twist.

\section{References}

Abdul Wahid, P.R. (2017). Translation of figurative language from English to Malay: An Analysis of the Translation of the Harry Potter Series. Proceedings of Research World International Conference, Phuket, Thailand, 9th-10th February, 2017.

Abdulla, A. K. (1994). The translation of style. Language, Discourse and Translation in the West and Middle East Benjamins Translation Library, 65.

Abrams, M.H. (1988). A Glossary of Literary Terms, New York: Rinehart and Winston.

Akdağ, T. \& Ural, G. (2017). Analysis of figurative elements in the novel the daughter of Smyrna. [online] Wjeis.org. Available at: http://www.wjeis.org/FileUpload/ds217232/File/08.gokhan_ural.pdf 
Adorno, T., Adorno, G., \&Tiedeman, R. (2002). Aesthetic Theory. 2nd ed. New York: Continuum.

Alwazna, R. (2014). Ethical aspects of translation: Striking a balance between following translation ethics and producing a $T T$ for serving a specific purpose. English Linguistics Research, 3(1).

Baalbaki, M. (2007). Oliver Twist, Beirut: Dar Al Elem Lel Malayen.

Bajnaid, A., Elyas, T., \& Veltri, G. (2019). Utilizing Matrimonial Web sites Among Saudi Users: An Empirical Study. Digest of Middle East Studies, 28 (1), 164-193.

Baker. M. (1992). A coursebook on translation. London: Routledge.

Bani Abdo, I. (2017). Stylistic issues of literary translation. Arabic and English. Germany: Noor Publishing.

Bernards, J. (2017). Figurative elements in mosaics and roman painting at Algarve (Portugal). Journal of Mosaic Research.

Dickens, C. (1982). Oliver Twist. Hong Kong: Oxford University Press.

Egudu, R.N. (1979). The Study of Poetry. Ibadan: Ibadan University Press.

Gasson, A. (1998, June 1). Wilkie Collins and Charles Dickens. Retrieved February/March, 2018, from http://www.wilkie-

collins.info/wilkie_collins_dickens.htm

Haan, M. D. (n.d.). The Translator's (In)visibility. Retrieved October 5, 2018, from https://www.hofhaan.nl/2011/martin-de-haan/the-translators-invisibility/

Jiang, Q. (2008). Aesthetic progression in literary translation. [online] Pdfs.semanticscholar.org.Availableat:https://pdfs.semanticscholar.org/4488/3d1 56e40fc696f5690a73ddc8dde0113d779.pdf

Munday, J. (2001). Introducing Translation Studies. London: Routledge.

Nida. E. (1964). Towards a science of translating: with special reference to principle and procedures involved in bible translating. Leiden, Netherlands: E.J. Brill. 
Nida. E. (1975). Language Structure and Translation. California, United States: Stanford University Press.

Nord, C. (2001). Loyalty and fidelity in specialized translation. The Translator, 7(2), 185-202.

Nord, C. (1997). Translating as a Purposeful Activity. St. Jerome Publishing

Peirce, C. S., Hartshorne, C., \& Weiss, P. (1932). Collected Papers of Charles Sanders Peirce. Cambridge: Harvard University Press.

Pym, A. (2012). On Translator Ethics. Benjamins Translation Library. doi:10.1075/btl.104

Shanaway, I. (2013, December 31). Chapter 1 الاول ترجمة الفصل وملخص له وتمارين مجابة الصف الاول الثانوى ترم اول. Retrieved from http://shanaway.ahlamontada.com/t21321-topic

Teilanyo, D. (2007). Figurative Language in Translation: A Study of J.P. Clark's The Ozidi Saga. Meta: Journal Des Traducteurs, 52(2), 309.

Trodd, Z. 2007. Hemingway's camera eye: the problem of language and an interwar politics of form. The Hemingway Review. 26(2), pp.7-21.

Vasilescu, R. (2015). Ethical issues in machine translation. Retrieved from https://www.researchgate.net/publication/279840673_Ethical_issues_in_machi ne_translation

Viehoff, R. (1986). How to construct a literary poem?. Poetics 15-3:287-306.

Wheeler, L.K. 2015. Literary vocabulary: literary terms and definitions: [Online]. [Accessed 20 February 2018]. Available from:

http://web.cn.edu/kwheeler/lit_terms_C.html

Williams, J., \& Chesterman, A. (2014). The Map A Beginners Guide to Doing Research in Translation Studies. Hoboken: Taylor and Francis.

Zhang, J. (2008). Images, imagination and image-gestalt in English-Chinese literary translation. Translation Journal, 12(2). 